\title{
Editorial
}

\section{US tax treaties: a new perspective}

\author{
Paul R. McDaniel, Hill \& Barlow, Boston
}

For the past ten years, the American Law Institute as part of its Federal Income Tax Project, has been examining the international tax system of the United States and has recommended a number of changes in that system. Many of those recommendations have already been reflected in statutory changes over the past five years.

The first part of the Project dealt exclusively with US statutory rules governing both inbound and outbound transactions. The statutory proposals have been officially adopted as positions of the American Law Institute. ${ }^{1}$

During the last three years, the International Tax Project has turned to consideration of issues arising in the context of US tax treaties. The reporters on the tax treaty project are Professor Hugh J. Ault, David R. Tillinghast, Esq., and Steven Shay, Esq. They have completed their report which includes their analysis and recommended proposals for US tax treaty positions. It is to be emphasized that the report has not yet been approved by the American Law Insitute and the positions in the report will not be final until a vote by the Institute in May 1991.

Nonetheless, because so many of the 1987 proposals by the ALI have been enacted, it is worth summarizing the reporters' suggestions at this time so that non-US readers can begin to assess the reporters' recommendations. If the reporters' recommendations are adopted by the ALI, given the history of the 1987 proposals, it seems likely that the new proposals regarding tax treaties will have a significant influence on US tax treaty policy.

In very summary form, the reporters' recommendations address the following topics:

1. The reporters recommend that a more restrained position be taken toward interpretation of tax treaties by the Internal Revenue Service and by US courts, i.e., by adhering more closely to the literal language of a treaty and giving greater weight to understandings of intent by the treaty partners and by multinational organizations rather than by relying more or less exclusively on US unilateral interpretive materials and decisions.

2. The reporters recommend that the US should observe international law in the context of treaty overrides and make some specific recommendations as to how the US should proceed when it wishes to adopt statutory provisions that conflict with existing treaty provisions.

3. The reporters recommend that mediation be considered as a mechanism to resolve conflicts between treaty countries that adopt inconsistent positions with respect to income determination. Binding arbitration is recommended by the reporters only if both countries and the taxpayer involved approve in the particular case at issue.

4. The reporters make recommendations with respect to exchange of information provisions and recommend that the US consider adoption of a treaty providing for reciprocal judicial enforcement of tax judgments.

5. With respect to the 'treaty-shopping' provisions that the US has been insisting on in recent tax treaties, the reporters conclude that the provisions now insisted upon by the US are too restrictive. The reporters suggest that treaty benefits should be available to a company if it is principally owned by one or more residents of any country with which the US has a comprehensive income tax treaty. In addition, it may be appropriate to require some sort of business nexus between the company seeking the treaty benefits in the US treaty partner country.

6. US treaties typically have little effect on US taxpayers because of the 'savings clause' generally included in US income tax treaties and because the foreign tax credit is available to offset double taxation. The reporters recommend that the US be open to recognizing 
the source of income rules of the treaty partner for purposes of computing the US foreign tax credit limitation.

7. The reporters finally include some interesting recommendations with respect to those US statutory rules which potentially invoke nondiscrimination clauses, including the branch profits tax and the tax on 'excess branch interest', consolidated returns where a foreign parent resides in a treaty country, liquidation of a US subsidiary into a foreign parent, and the much-discussed 'earnings-stripping' provision enacted in 1989.

The reporters' study of the US tax treaty system, both in its analysis of policy issues and technical applications, constitutes a major development of the standards which should be applied to assessment of US tax treaty provisions. If the reporters' recommendations are adopted by the American Law Institute in May, they will deserve the closest attention by all persons, both foreign and US, who are involved in and interested in tax treaty issues. 